\title{
Plant Growth Promoting Rhizobacteria Improve the Production and Enhancement of Alkaloid Content in Chilli
}

\author{
Moumita Datta ${ }^{1}$, Dipak Paul ${ }^{2}$, Sankar Narayan Sinha ${ }^{2}$, Chandan Sengupta ${ }^{2,}$, \\ ${ }^{1}$ Department of Botany, Raghunathpur College, Raghunathpur, Purulia, West Bengal, India \\ ${ }^{2}$ Microbiology Section, Department of Botany, University of Kalyani, Kalyani, West Bengal, India
}

\section{Email address:}

dattamoumita2005@yahoo.co.in (M. Datta),dipak23paul@yahoo.com (D. Paul), sinhasn62@yahoo.co.in (S. N. Sinha), chandansenguptaku@gmail.com (C. Sengupta)

\section{To cite this article:}

Moumita Datta, Dipak Paul, Sankar Narayan Sinha, Chandan Sengupta. Plant Growth Promoting Rhizobacteria Improve the Production and Enhancement of Alkaloid Content in Chilli. Frontiers in Environmental Microbiology. Vol. 1, No. 2, 2015, pp. 24-26.

doi: $10.11648 /$ j.fem.20150102.13

\begin{abstract}
Chilli (Capsicum annuum L.) is an important vegetable. Plant growth-promoting rhizobacteria (PGPR) are beneficial as they colonize roots of plant and accelerate plant growth by different ways. In the present study, the impact of plant growth promoting rhizobacteria (PGPR) like Streptomyces sp. and Bacillus sp. on growth parameters and the production of capsaicin alkaloid are investigated in local variety of chilli. From the results of this investigation, it can be concluded that the seedling treatment of PGPRs can be used as a good technique in the enhancement of yield and alkaloid contents in plant cultivation, as it provides an ecofriendly approach.
\end{abstract}

Keywords: Chilli, PGPR, Seedling Treatment, Capsaicin

\section{Introduction}

Chilli (Capsicum annuum L.) is an important vegetables as well as spice throughout the world. In India, chilli is consumed in different ways as vegetable, spice, pickles, sauce etc. Chillies are important source of vitamin A, vitamin B, vitamin $\mathrm{C}$ and vitamin $\mathrm{E}$ with minerals like copper, folate, manganese, molybdenum, potassium and thiamin etc $[1,2]$. It was observed that chilli contains 7 times more vitamin $\mathrm{C}$ than orange [3]. Chillies have been incorporated in Ayurvedic medicines which are used as tonic to eradicate many diseases. Apart from its versatile utility, the world loves its pungency which is due to the presence of a crystalline volatile alkaloid called capsaicin, and its analogues and derivatives which is (collectively known as capsaicinoids) present in the skin, septa and fruits [4]. As a medicine, capsaicin is used as a anti-irritant in neuralgia, lumbago and rheumatic disorders. Capsaicin also has a tonic cum carminative action but if taken inordinately, problem of gastro-enteritis may arise. The enzyme isolated from chilli is used in the treatment of certain types of cancer.

In agriculture, plant growth promoting rhizobacteria (PGPR) are familiar for their great impact on the associated vascular plants. For many crops, such bacteria are an inevitable part of management programs. Previous report shows that the occurrences of Azospirillum, Azotobacter, Pseudomonas and
Bacillus in the rhizosphere of medicinal plant like Aloe vera $[5$, 6]. Microbial consortium enhances the alkaloid content in Aloe vera [7].

The use of bacteria is the aim of improving quality and quantity of chilli. The role played by PGPR in relation to chilli and their effect on the production of alkaloid is an area of this paper.

\section{Materials and Methods}

\subsection{Selection of Bacterial Strains}

Two bacterial strains viz. Streptomyces sp. and. Bacillus sp. were collected from microbiology laboratory, Department of Botany, University of Kalyani, West Bengal, India which has plant growth promoting activity.

\subsection{Collection of Seeds}

Chilli seeds of local cultivar popularly called 'Bullet' were collected from a progressive farmer of Madandanga village, Nadia, West Bengal, India used as the planting materials. Seeds were stored in dry places for further use.

\subsection{Pot Experiment of Selected Isolate}

Chilli seeds (cv. Bullet) were sown separately in a seed 
bed and properly maintained. After the 45 days of sowing, plantlets were uprooted carefully and the root portion was placed in individual culture broth (approximately $10^{6}$ cells/ml cell density) for 30 minutes. Pots measuring 14 inch diameter were prepared with finely grinded soil and sand. The seedlings were then transferred into pots and allowed to stand for 135 days. The mean value of each treatment was used for analysis. Different parameters like plant height, canopy width, number of fruits, weight of fruits, length of fruits etc. were noted down.

\subsection{Capsaicin Quantity Test}

Colorimetric estimation of capsaicin was done following the method of North [8]. Chillies (10 g) were crushed with mortar and pestle and little amount of $60 \%$ acetone. Finally colorimetric estimation was done by using phosphotungsticphosphomolybdic acid reagent in UV-VIS spectrophotometer (Shimadzu UV 1601-PC) and the capsaicin quantity was measured against a previously prepared standard curve.

\section{Results and Discussion}

Microorganisms living in the plant rhizosphere interact with each other and with plant roots in several ways that affect plant growth and development [9]. In this present experiment, the role of two test isolates which showed promising performance as PGPR and biocontrol potential, were checked for their effects on different parameter of chilli plant growth. Seedling after being soaking with bacterial suspension was in pots in control condition of net house and allowed to grow for 135 days. Observations on different growth parameters are shown in Table 1. Results revealed that quality and quantity increased in PGPR treated plants over control. Bacillus is known to induce increased growth of various crops through production of growth regulating factors [10]. Previously similar types of studies were done on some medicinally important plants like Catharanthus roseus [11] and Coleus forskohlii [12].

Capsaicin content in fruits of chilli treated with Streptomyces and Bacillus isolates were compared with controls (water and medium treated plants) and depicted in Figure 1. It was found that all the plants treated with bacterial isolate (Streptomyces and Bacillus) had greater in capsaicin content in fruits as compared to control. Bacillus treated plant showed the best results among the two isolate treated plants. In the present study, both the PGPRs enhance the crop quality and quantity and also increase the alkaloid content in fruit.

Table 1. Effect of bacterial isolates on growth and fruit characters of chilli (cv. Bullet).

\begin{tabular}{|c|c|c|c|c|c|c|c|}
\hline Treatment & $\begin{array}{l}\text { Average plant height } \\
\text { at } 90 \text { DAT }(\mathrm{cm})^{\text {b }}\end{array}$ & $\begin{array}{l}\text { Plant canopy } \\
\text { width }(\mathrm{cm})^{\mathrm{b}}\end{array}$ & $\begin{array}{l}\text { Total number of } \\
\text { fruits/ }^{\text {plant }}{ }^{b}\end{array}$ & $\begin{array}{l}\text { Fruit weight } \\
(\mathrm{g})^{\text {b }}\end{array}$ & $\begin{array}{l}\text { Fruit length } \\
(\mathrm{cm})^{\mathrm{b}}\end{array}$ & $\begin{array}{l}\text { Fruit width } \\
(\mathrm{cm})^{\mathrm{b}}\end{array}$ & $\begin{array}{l}\text { Number of } \\
\text { seeds }^{\text {b }}\end{array}$ \\
\hline Streptomyces $^{a}$ & $53.25 \pm 3.48$ & $70.25 \pm 4.00$ & $64.5 \pm 2.32$ & $1.92 \pm 0.04$ & $5.65 \pm 0.12$ & $0.86 \pm 0.02$ & $76.75 \pm 4.21$ \\
\hline Bacillus $^{a}$ & $44.75 \pm 1.66$ & $64.25 \pm 3.82$ & $55.25 \pm 3.55$ & $1.98 \pm 0.06$ & $6.25 \pm 0.36$ & $0.84 \pm 0.01$ & $78.25 \pm 4.22$ \\
\hline$W^{d}$ & $34 \pm 2.38$ & $47.25 \pm 3.28$ & $39.25 \pm 2.98$ & $1.27 \pm 0.04$ & $5.12 \pm 0.42$ & $0.58 \pm 0.02$ & $27.5 \pm 1.51$ \\
\hline
\end{tabular}

a Name of isolate; b Average of 4 pots: 1 plant/pot; c Medium control; d Water control; DAT: Days after treatment.

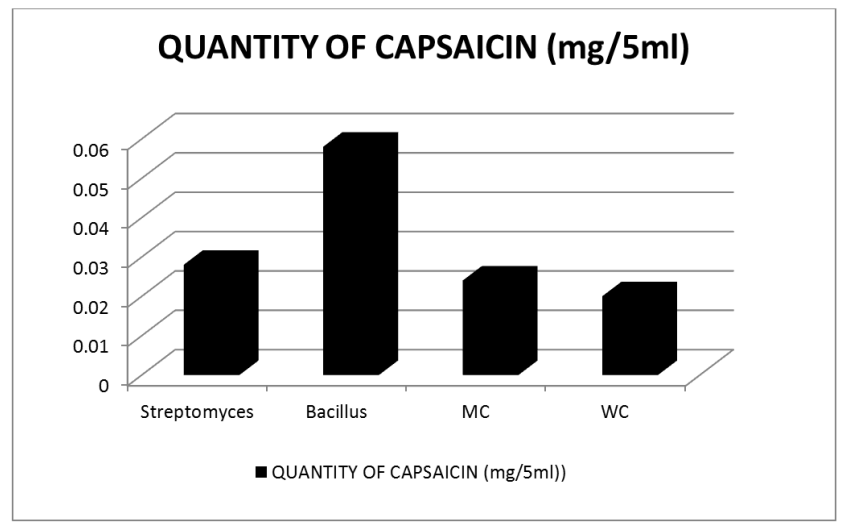

Figure 1. Different treatment shows capsaicin quantity $M C=$ Medium control $W C=$ Water control.

\section{Conclusion}

From this investigation, it was revealed that the seedling treatment of PGPRs (Streptomyces sp. and Bacillus sp.) can be used as a potent method in the increment of yield and alkaloid contents in chilli plant cultivation, which is an environmentally-friendly approach.

\section{References}

[1] Simonne AH, Simonne EH, Eitenmiller RR, Mills HA, Green NR. (1997). Ascorbic acid and provitamin A contents in unusually colored bell peppers (Capsicum annuum L.). Journal of Food Composition and Analysis 10(4):299-311.

[2] Marín A, Ferreres F, Tomás-Barberán FA, Gil MI. (2004). Characterization and quantitation of antioxidant constituents of sweet pepper (Capsicum annuum L.). Journal of Agricultural and Food Chemistry 52(12):3861-3869.

[3] Swamy S, Krupakar A, Chandran DS, Koshy EP. (2015). Direct regeneration protocols of five Capsicum annuum L. varieties. African Journal of Biotechnology 13(2):307-312.

[4] Borges RM (2001) Why are chillies pungent? Journal of Biosciences 26(3): 289-291.

[5] Thosar NJ, Ingle VG, Jadhar JC. (2005) Effect of FYM and Biofertilizers on dry root and seed yield of Ashwagandha (Withania somnifera).Crop Production 1:27-28.

[6] Attia FA, Saad OAO (2001) Biofertilizers as potential alternative of chemical fertilizer for Catharanthus roseus $G$. Don. Journal of Agricultural Science 26:7193-7208. 
[7] Ashok T, Kalaiarasu S (2014) Studies on the effect of PGPR cells for the maximization of alkaloid content in Aloe vera. Golden Research Thoughts 4(4):1-4.

[8] North H (1949) Colorimetric determination of capsaicin in oleoresin of capsicum. Analytical Chemistry 21(8):934-936.

[9] Lambers H, Mougel C, Jaillard B, Hinsinger P (2009) Plantmicrobe-soil interactions in the rhizosphere: an evolutionary perspective. Plant and Soil 321(1-2):83-115.

[10] Sivasakthi S, Usharani G, Saranraj P (2014) Biocontrol potentiality of plant growth promoting bacteria (PGPR)-
Pseudomonas fluorescens and Bacillus subtilis: A review. African Journal of Agricultural Research 9(16):1265-1277.

[11] Karthikeyan B, Jaleel CA, Azooz MM 2009. Individual and combined effects of Azospirillum brasilense and Pseudomonas fluorescens on biomass yield and ajmalicine production in Catharanthus roseus. Academic Journal of Plant Sciences 2(2):69-73.

[12] Damam M, Gaddam B, Kausar R (2014) Effect of plant growth promoting rhizobacteria (PGPR) on Coleus forskohlii. International Journal Current Microbiology and Applied Sciences 3(9):266-274. 